\title{
Development Protected Cultivation in Horticulture Product: Feasibility Analysis in West Java Province
}

\author{
Nita Kuswardhani *, Peeyush Soni* and Ganesh P. Shivakoti* \\ \# Agriculture Technology Faculty, Jember University, Indonesia \\ E-mail:nita8994@yahoo.com
}

* Agricultural Systems and Engineering, Asian Institute of Technology, Thailand

\begin{abstract}
The development of agricultural system cannot be solved only through technological changes but also necessary to change the strategy of agricultural system as a whole. The aim of this research was to assess the factor of strengths, weaknesses, opportunities and threats (SWOT) analysis that can be used to identify relevant economic, ecological and societal (EES) issues for the assessment of sustainable development in protected cultivation in West Java Province. The potential of protected cultivation was higher energy productivity than open field production, indirect energy and renewable energy were the main source of energy. The ratio of output to input energy was higher in greenhouse production $(0.85,0.45$ and 0.49$)$ than open field (OF) vegetable production (0.52, 0.175 and 0.186$)$ for tomato, and chili. Financial analysis revealed higher mean net returns from greenhouse vegetable production as $7043 \$ /$ ha $(922-15,299 \$ / \mathrm{ha})$ when compared to $563 \$ / \mathrm{ha}(43-1,172 \$ / \mathrm{ha})$ from open field vegetable production. Among the greenhouse vegetables, tomato cultivation was the most profitable in terms of energy efficiency and financial productivity. Generally, reducing pest and disease in vegetable production is a main expectation from newly adopted technology. Limited land holding size of agricultural fields, high capital investment and lack of infrastructure were the constraints in improving their production through new technology. Low price of the product and lack of adequate market were also the other problems with vegetable production. Inadequate government support in term of training and financial support to farmers in certain areas make it difficult in protected cultivation technology. Capacity building of farmers, research and development on protected cultivation, manufacturing and financial sector support, supporting an efficient and adequate marketing system of protected cultivation product, and development of an agribusiness area especially for export commodities are the strategies suggested to develop and improve technology in cultivation toward sustainable agriculture.
\end{abstract}

Keywords - Protected cultivation, SWOT analysis, Strategic planning, Sustainable agriculture, West Java Province

\section{INTRODUCTION}

Agriculture contributes $14.7 \%$ of Gross Domestic Product (GDP) in Indonesia [1]. Even though this sector less share of GDP but this sector is known as one of the most important ones in term of providing employment agro-horticultural commodities is a very important role in non-oil exports.

Total production of vegetable in 2012 is 11 million tons that increase $3.9 \%$ from the production in 2011. Even though the production increase but vegetable showed the slight increase in harvested area [2]. In general, the main cause in cultivated area and stagnant production are caused by unsuitable climate with higher rainfall and higher wind velocity. The farmer did not want to take a risk of cultivating vegetables and ornamental plants. Another possible reason was there was shifting of agricultural land use to nonagricultural sub sectors.
As the most productive area for vegetable cultivation, West Java province, improve quality and quantity by using protected cultivation is essential to fulfill the demand of horticultural crop in Indonesia. Creating low cost technology such as adapted low cost protected cultivation will make a greater contribution of vegetables, especially tomato, to the stability of a farmer's income in the medium areas [3]. Through protected cultivation, products will be available continuously throughout the year, spread labor demand and higher farmer's income.

The development of worldwide protected cultivation to produce horticultural products with relatively safe and health products for human life has increased due to the increase of demand for fruits/vegetables (as increasing world population), and rising standard of living. This technology was also one of the promised technology adopted that 
influence in increasing income of the farmer and overcome the limitation on agricultural land for horticultural product.

Since agriculture plays the important role in many developing countries, adoption of technological innovations in agriculture has attracted considerable because new technology apparently offers opportunity to increase that production substantially. Clearly, a technology that is being adopted has an edge over conventional practices. Technology innovation covers its advantage and benefit of the people who adopt it [4].

Therefore in this study, we attempt to assess problem and constraint of potential protected cultivation in West Java Province and to identify the factor of strengths, weaknesses, opportunities and threats (SWOT) analysis that can be used to identify relevant economic, ecological and societal (EES) issues for the assessment of sustainable development in protected cultivation in West Java Province.

\section{MATERIALS AND METHODS}

Research area. The study was conducted in Sukabumi (in medium and highland) and West Bandung regency (in highland), West Java Province, Indonesia. These two regency are of the most agricultural importance, which produce a large amount of horticultural product (chili, tomato and lettuce) to local or national market even export market.

Sukabumi regency has an area of 420,000 ha with altitudes ranging from 0 to $2,958 \mathrm{~m}$ above the sea level (a.s.l). The Sukabumi regency is geographically located between $6^{\circ} 57^{\prime}$ to $7^{\circ} 25^{\prime}$ South latitude and $160^{\circ} 49^{\prime}$ to $107^{\circ}$ $00^{\prime}$ East longitude and has an area of 412,800 ha which is $11.21 \%$ of the West Java province or $3.01 \%$ of the of Java Island. The average rainfall is $144 \mathrm{~mm}$ to $2805 \mathrm{~mm}$ and the average temperature is 20 to $30^{\circ} \mathrm{C}$ with a relative humidity in the range of 85 to $91 \%$. Based on the data from central bureau of statistic Sukabumi, Sukabumi regency produce 583,032 tons vegetables in which the major vegetables are tomato, petsai, chili, cucumber and mushroom in 2011[5].

The West Bandung regency has 130,577 ha area spread over $60^{\circ} 41^{\prime}$ to $70^{\circ} 19^{\prime}$ South latitude and $107^{\circ} 22^{\prime}$ to $108^{\circ} 05^{\prime}$ East longitude, with an average altitude of $110 \mathrm{~m}$ and maximum 2,242.9 $\mathrm{m}$ above mean sea level. The average annual rainfall is 1500 to $4000 \mathrm{~mm}$ and average temperature is $19^{\circ} \mathrm{C}$ to $24^{\circ} \mathrm{C}$ [6]. This regency has agribusiness superior commodity especially horticulture and animal husbandry. Such superior horticultural commodity are vegetables (tomato, chili, stringbean), cut flower (rose, gerbera, crissantium), and fruits (citrus, lemon, banana, and pineapple). The potential animal husbandry are dairy cow, cattle beef, and duck.

Data Collection and analysis. Data were collected during 2011 production season. The total respondent of protected cultivation farmer who grew vegetable in both regencies is 27 farmers. Furthermore, since the farmer usually used low cost greenhouse, net house with plastic roof was surveyed for this study. Based on the main vegetable production, the survey focused on tomat, chili and lettuce. Tomato and chili can grow in 2 seasons but mostly, farmer grow lettuce after rainy season, April to October.

Identification of problems and constraint was collected by giving the rank for crop production and marketing factor of the horticultural product. Data was analyzed by using the Weighted Average Index (WAI) and statistical analysis. For this matter, the statistical test for qualitative variable was done by constructing indexes based on scaling [7]. Meanwhile SWOT factor was collected through questionnaire about the strength and weakness obtained from key informants/person of the production and marketing system of vegetable production under protected cultivation. The survey was given to key person, such as agriculture department officer, agriculture extension worker, head of farmer group, head of sub regency/district (study area) and researcher. The number of respondents were selected by using the purposive sampling method. The secondary data were collected from the Department of Agriculture of Indonesia, Indonesian Centre of Research and Development of horticultural crop, and other related offices.

\section{RESULTS AND DISCUSSION}

Potential of protected cultivation in West Java Province. The potential of protected cultivation of tomato, chili and lettuce product in West Java province was found that the crop yield of horticultural product was almost double compare on open field production [8-11].

Energy output-input ratio in protected cultivation production was also higher in protected cultivation production. [11] was found that 0.85 for tomato, 0.45 for chili medium land, 0.49 for chili in highland and 0.15 for lettuce. Except lettuce, this ratio in open field production was merely half that of in greenhouse production.

Indirect energy was the main source of energy that used in protected cultivation ([11-12]). Non renewable energy sources among the inputs had a share of more than $50 \%$ of the total input ([11], [13]).

The economic analysis also found there was positive cash flow in protected cultivation production [14-16]. It also found that protected cultivation for vegetable production has a a higher higher $\mathrm{B} / \mathrm{C}$ ratio than open field production, such as 1.43 for tomato, 1.32 for chili medium land and 1.9 for chili highland [11]. Other researchers reported similar results for some crops under greenhouse vegetable production, such as; 1.74 for strawberry [17], 1.68 for cucumber, 3.28 for tomato[13], 1.83 for grape [18], 1.57 for tomato, 1.15 for pepper, 1.29 for cucumber, 1.10 for eggplant [19-20]. Tomato has also higher financial produced with $3.2 \mathrm{~kg} / \$$ [11].

Problems and constraints. In this study, identification of problem and constraint was classified for crop production and marketing based on perception of farmers. All the data was analyzed based on the index and magnitute cause of each factors.

Several problems and constraints were expressed by the farmer for vegetable production and marketing. Insect, diseases, quality of infrastructure, seed shortage, fertilizer shortage, lack of pesticide, capital, labor, water/irrigation, media and other inputs, price fluctuation and technical information were the problems of vegetable production that identified by the farmers. Meanwhile, lack of market, low price of the product, lack of storage, lack of transport, lack of market info, brokers, fair sales and perishability were the marketing problem that may occur which identified by farmers too. All these problems were ranked as per the 
degree of importance. The degree of importance of problems and constraints in vegetable production and marketing is shown in Tables 1 and 2 respectively.

Base of the WAI (weighted average index) values (Table 1), it shows that the first problem for vegetable production in Sukabumi medium land was insect (0.91), followed by capital (0.91) and disease (0.87). In Sukabumi highland, the insect $(0.93)$ is the most problem for vegetable production, followed by disease (0.88) and capital (0.86). Meanwhile, in West Bandung, the highest ranked of problem in crop production was capital $(0.89)$, followed by insect $(0.88)$ and disease $(0.85)$.

TABLE I

DEGREE OF IMPORTANCE OF PRODUCTION PROBLEM IN VEGETABLE PRODUCTION

\begin{tabular}{|l|c|c|c|c|c|c|}
\hline & \multicolumn{2}{|c|}{$\begin{array}{c}\text { Sukabumi - } \\
\text { medium land }\end{array}$} & \multicolumn{2}{c|}{$\begin{array}{c}\text { Sukabumi - } \\
\text { highland }\end{array}$} & \multicolumn{2}{c|}{$\begin{array}{c}\text { Wandung- } \\
\text { highland }\end{array}$} \\
\cline { 2 - 7 } & WAI & MC & WAI & MC & WAI & MC \\
\hline Insects & 0.91 & HM & 0.93 & HM & 0.88 & HM \\
\hline Diseases & 0.87 & HM & 0.88 & HM & 0.85 & HM \\
\hline $\begin{array}{l}\text { Quality of } \\
\text { infrastructure }\end{array}$ & 0.28 & LM & 0.4 & MM & 0.08 & LM \\
\hline Seed shortage & 0.55 & MM & 0.51 & MM & 0.49 & MM \\
\hline Fertilizer shortage & 0.48 & MM & 0.4 & MM & 0.4 & MM \\
\hline Lack of pesticide & 0.43 & MM & 0.49 & MM & 0.44 & MM \\
\hline Capital & 0.91 & HM & 0.86 & HM & 0.89 & HM \\
\hline Labor & 0.33 & LM & 0.29 & LM & 0.23 & LM \\
\hline Water /irrigation & 0.56 & MM & 0.25 & LM & 0.44 & MM \\
\hline $\begin{array}{l}\text { Media and other } \\
\text { inputs }\end{array}$ & 0.48 & MM & 0.5 & MM & 0.5 & MM \\
\hline Price fluctuation & 0.53 & MM & 0.53 & MM & 0.7 & HM \\
\hline $\begin{array}{l}\text { Technical } \\
\text { information }\end{array}$ & 0.41 & MM & 0.53 & MM & 0.6 & MM \\
\hline
\end{tabular}

Note $: \mathrm{MC}=$ magnitute of cause $; \mathrm{LM}=$ low magnitute $=0.1-0.33 ; \mathrm{MM}=$ moderate magnitute $=0.34-0.67 ; \mathrm{HM}=$ high magnitute $=0.68-1$

Lack of capital was also a major problem for farmers in vegetable production in both regencies. Therefore, farmers needed more cash on hand. It implies that there is difficulty in on accessing capital investment for farmers to produce vegetable. An excellent relationship between the farmers and the financial institution is normally an essential requirement in obtaining financing. And also introducing new technology with low capital investment such as greenhouse is more preferable in West Java province.

Farmer in Sukabumi regency has suffered from price fluctuation of input and product, which effect on their income. Consequently, they could not easily adopt greenhouse technology. Meanwhile, farmer in West Bandung faced difficulties of the low quality of infrastructure that effect on the shortage of agricultural input such as seed, fertilizer, pesticide, etc., but they had no problem in the capital investment. Farmers in this area were willing to increase their production and income by using greenhouse technique as long as it was supported with increasing quality of infrastructure. Labor have the lowest index in both regencies. It means that there is plenty of agricultural labor in those regency. Majority people work in agriculture sector in West Java province.

It is also found that insect, disease, capital, media and other input are highest significant different among the study area for some causes which also depicts the three areas have different perception on this issue although they have higher levels of WAI. Farmer in Sukabumi highland pointed out that the insect and disease incursion frequently occurred more than other regency that effect on vegetable production. Only on the quality of infrastructure is not a significant difference. It means that all the farmers in study area thought that having good infrastructure will effect on improving vegetable production.

Based on the finding, the farmers in Sukabumi as well as West Bandung regency had a marketing problem regard to the low price of the product and lack of market for. In many cases, the middlemen tend to control the vegetable prices and supply materials necessary for vegetable production such as fertilizer, seed, and pesticides. And also a major route of vegetable is based on the middlemen who buy vegetables directly on farms and send it to urban areas or "pasar induk". It can be seen that farmers never satisfied with current middlemen's pricing system. Basically, small farmer was quite difficult to control the price of the product (as price taker) especially for the open field vegetable production. The degree of importance of marketing problem and constraints is shown in Table 2.

TABLE II

DEGREE OF IMPORTANCE OF MARKETING PROBLEM IN VEGETABLE PRODUCTION

\begin{tabular}{|l|c|c|c|c|c|c|}
\hline \multirow{2}{*}{} & \multicolumn{2}{|c|}{$\begin{array}{c}\text { Sukabumi - } \\
\text { medium land }\end{array}$} & \multicolumn{2}{c|}{$\begin{array}{c}\text { Sukabumi - } \\
\text { highland }\end{array}$} & \multicolumn{2}{c|}{$\begin{array}{c}\text { West } \\
\text { Bandung- } \\
\text { highland }\end{array}$} \\
\cline { 2 - 8 } & WAI & MC & WAI & MC & WAI & MC \\
\hline Lack of market & 0.42 & MM & 0.32 & LM & 0.36 & MM \\
\hline Low price & 0.74 & HM & 0.76 & HM & 0.84 & HM \\
\hline Lack of storage & 0.71 & HM & 0.76 & HM & 0.51 & MM \\
\hline Lack of transport & 0.49 & MM & 0.45 & MM & 0.38 & MM \\
\hline $\begin{array}{l}\text { Lack of market } \\
\text { info }\end{array}$ & 0.45 & MM & 0.56 & MM & 0.57 & MM \\
\hline Brokers & 0.55 & MM & 0.59 & MM & 0.57 & MM \\
\hline Fair sales & 0.39 & MM & 0.42 & MM & 0.58 & MM \\
\hline Perishability & 0.74 & HM & 0.63 & MM & 0.7 & HM \\
\hline
\end{tabular}

Note : $\mathrm{MC}=$ magnitute of cause $; \mathrm{LM}=$ low magnitute $=0.1-0.33 ; \mathrm{MM}=$ moderate magnitute $=0.34-0.67 ; \mathrm{HM}=$ high magnitute $=0.68-1$

In comparison between two regencies, the majority of farmers in the Sukabumi highland had lack of market. Their market depended on the traders who came to their field, estimated the volume of production and negotiated the price with the buyers. Some of the farmers did not have a choice to sell their product through the local traders because most of the trader were their own relatives and their neighbor. All the activities for harvesting and shipping could be done by the traders themselves. Other reasons are small volume of selling vegetable production. The farmer had no time to sell 
vegetables by themselves and some of the traders give the farmer advance credit. Therefore, low price is the major marketing problem and constraint for farmers. For farmers who grew vegetable under greenhouse, price fluctuation is not the main problem because majority of them already had their own market and contract with the market.

SWOT Analysis. SWOT analysis is a methodology allowing an industry to understand and plan to use their strengths to exploit opportunities, to recognize and repair or avoid their weaknesses, and to defend against or sidestep any known threats. The method has been widely used as a strategic planning tool and found it was effective[21].

The internal factors were viewed as strengths or weaknesses depending upon their impact on the organization's objectives. Strengths represents with respect to one objective was the weaknesses for another objective. 4P's as well as personnel, finance, manufacturing capabilities, and so on was all the factors that included in this point. Meanwhile the external factors included technological change, macroeconomic matters, legislation, and socio-cultural changes, as well as competitive position or some changes in the marketplace. The result of SWOT analysis of this research was:

\section{A. Strengths $(S)$}

1. Topography is favorable for vegetable production.

2. The majority of households are engaged in agriculture and having long experience in agriculture.

3. Good environment (climate, soil and water).

4. Efficiency in energy input

5. Agricultural input availability in abundance

6. Higher income than open field vegetable production.

7. Good infrastructure

8. Positive attitude of farmers on new technology introduced.

9. Big niche markets are available in West Java Province.

B. Weaknesses $(W)$

1. Most of the youths in selected regency are not attracted towards agriculture.

2. Mindset of the farmers to go with traditional agriculture practice and crops.

3. Most of the greenhouse area with farmers having small land holding size

4. Inefficient distribution process.

5. Government support is still inadequate

6. Knowledge and technology gaps in greenhouse management are prominent.

7. Lack of marketing information

8. Lack of capital/credit for investment

9. Farmer's group, cooperative, association and bank did not work cohesively together

10. No bargaining power of farmer.

11. High utility cost

12. Majority of the greenhouses is subsidy driven and farmer could not maintain it after the greenhouse are constructed.

\section{Opportunities $(O)$}

1. High product demand

2. Horticulture is a strategic sector.

3. Higher technology and training available.

4. Higher technology equipment available.

5. Large population of educated youth can be motivated and trained in field of protected cultivation.

6. Communication technology is inspiring and becoming less costly.

7. Consumer awareness of low pesticide vegetable production under protected cultivation.

8. Promotion and extension provided by Government office

9. On farm additional value addition to fresh produce as possible

10. Development of industrial and service sector lead to the higher demand of good quality vegetable production

11. Increasing tropical horticultural product for domestic and export demand

\section{Threat $(T)$}

1. Import vegetable has lower price than local vegetable

2. Pest and disease are the main problem when the greenhouse structure grow older.

3. The business climate is not conducive and the competition is not fair enough for the farmer.

4. Lack of standard in of protected cultivation.

5. Lack of standart post harvest management practices of produce.

6. Inefficiency of farm management makes farmers difficult to get the advantages of globalization and trade liberalization

Based on the internal and external factor, the possibility strategy that can develop the protected cultivation was the strategy who involve the government/ institution instead of development the farmer skill itself.

\section{CONCLUSIONS}

For the feasibility analysis it was found that protected cultivation for vegetable production has potential in term of productivity, energy efficiency and economic analysis. But the development of protected cultivation requires managerial skills, patience, and hard work from a grower, and government / institution support. The awareness, incentives, training, better sustained return, continuous support to the farmer in production mode would be constitute appropriate strategy for accelerating production of vegetable crops using protected cultivation in West Java Province.

\section{ACKNOWLEDGMENT}

We would like to thank to Asian Institute of Technology, Thailand and the General Directorate of Higher Education (DIKTI), Indonesia. 


\section{REFERENCES}

[1] BPS. (2014). Statistik Indonesia 2012 (Statistical Yearbook of Indonesia 2012). Central Bureau of Statistics, Jakarta, Indonesia.. Available at http://www.bps.go.id

[2] Direktorat Jendral Hortikultura.. Data Luas Area Tanaman Sayuran di Indonesia. 2013. Available at http://horti.pertanian.go.id/article

[3] Adiyoga W., Suwandi, Budi Jaya and Rustaman E.S.. Evaluasi Awal Budidaya tomat dataran Rendah/Medium (Evaluation of Tomato Cultivation in Low/Medium lands). Buletin Penelitian Hortikultura, Tahun 1992, Volume XXI, Nomor (3). 1992. Retrieved from http://www.scribd.com/doc/17557813/Evaluasi-Awal-BudidayaTomat-Dataran-Rendahmedium

[4] Rogers, E.M. Diffusion of innovations (5th ed.). New York: Free Press. 2003

[5] BPS Kabupaten Sukabumi. (2012). Kabupaten Sukabumi dalam angka 2010. http://sukabumikab.bps.go.id.

[6] Kabupaten Bandung Barat. (2011). Kabupaten Bandung Barat dalam angka 2010. Badan Pusat Statistik (BPS).

[7] Miah, A.Q.. Applied statistics: a course handbook for human settlements planning. Asian Institute of Technology. 1993.

[8] Jensen, M.H.. Food Production in Greenhouse. In E. Goto, K.kurata, M.Hayashi and S. Sase. (Eds). Plant Production in Closed Ecosystem. Kluwer Academic Publisher, Dodrecht-Boston-London. 1997.

[9] AVRDC.(2000). Manila peri-urban Vegetable Project. [Online]. Availabel: http://www.avrdc.org/pdf/00annual report/manila.pdf

[10] Singh, Balraj and N.P.S. Sirohi.. Protected Cultivation of Vegetables in India: Problems and Future Prospects. Proc. IS on Greenhouses, Environmental Controls \& In-house Mechanization for Crop Production in the Tropics and Sub-tropics . Acta Hort. (ISHS), 2006,710 .

[11] Kuswardhani N, P. Soni, G.P. Sivakhoti. Comparative energy inputoutput and financial analyses of greenhouse and open field vegetables production in West Java, Indonesia. Energy 2012, Vol. 53, 83-92.
[12] Ozkan B, R. Figen Ceylan and Hatice Kizilay. Energy input and crop yield relationships in greenhouse winter crop tomato production. Renewable Energy 2011,36(11), 3217-21.

[13] Heidari, MD and M. Omid. Energy uses pattern and economometric model of major greenhouse vegetable production in Iran. Energy 2011, 36(1), 220-225.

[14] Illias M.K, Hawa J., Rezuwan K. and Mohd. Khairol, MK.. Vegetable Production Under Rainshelter. MARDI Senior Staff Conference, Hilton, Kuala Lumpur. 1992.

[15] Khairol M.A., Redzuan M.S. Mohd., H. N Auni and A. Roslina. The Prospect of Tomato Production under Rainshelter in Malaysia Proc. IS on Greenhouses, Environmental Controls \& In-house Mechanization for Crop Production in the Tropics and Sub-tropics. Acta Hort (ISHS). 2006, 710.

[16] Al-Abdulkader Mohd. A. Financial Analysis of Greenhouse Vegetable Specialized Projects in Saudi Arabia Proc. IS on Greenhouses, Environmental Controls \& In-house Mechanization for Crop Production in the Tropics and Sub-tropics. Acta Hort. (ISHS) 2006,710 .

[17] Banaeian N, Omid M, and Ahmadi H. Energy and economic analysis of greenhouse strawberry production in Tehran province of Iran. Energy Convers Manage 2011, 52(2), 1020-5.

[18] Ozkan B, Cemal Ferta and C. F. Karadeniza. Energy and cost analysis for greenhouse and open-field grape production. Energy 2007, 32(8), 1500-1504.

[19] Canakci M, and I. Akinci. Energy use pattern analyses of greenhouse vegetable production. Energy 2006, 31(8-9), 1243-56.

[20] Soni P, Taewichit C, and Salokhe V.M. Energy Consumption and $\mathrm{CO} 2$ Emissions in Rainfed Diversified Agricultural Production Systems of Thailand. Agricultural Systems Accepted for publication. 2013.

[21] Rangkuti F. Analisis SWOT Teknik Membedah Kasus Bisnis. PT. Gramedia Pustaka Utama. Jakarta. 2006. 